\begin{tabular}{|c|c|c|}
\hline 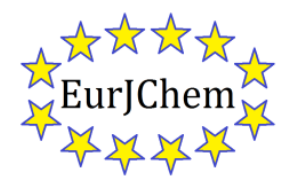 & $\begin{array}{c}\text { European Journal of Chemistry } \\
\text { Journal homepage: } \text { www.eurjchem.com }\end{array}$ & 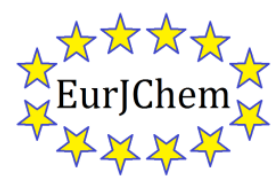 \\
\hline
\end{tabular}

\title{
Thermodynamic investigation of a new water-soluble porphyrin with calf thymus DNA
}

\author{
Hamid Dezhampanaha,*, Abdol-Khalegh Bordbarb and Shahram Tangestaninejad ${ }^{\mathrm{b}}$ \\ a Department of Chemistry, Faculty of Science, University of Guilan, Rasht, IR-0098, Iran \\ b Laboratory of Biophysical Chemistry, Department of Chemistry, University of Isfahan, Isfahan, IR-81746-73441, Iran \\ *Corresponding author at: Department of Chemistry, Faculty of Science, University of Guilan, Rasht, IR-0098, Iran. Tel.: +98.131.3233262; fax: +98.131.3233262. \\ E-mail address: h.dpanah@guilan.ac.ir (H. Dezhampanah).
}

\section{ARTICLE INFORMATION}

\section{Received: 07 June 2010}

Received in revised form: 10 July 2010

Accepted: 21 September 2010

Online: 31 December 2010

\section{KEYWORDS}

\section{Porphyrin}

Thermodynamics of binding

Optical absorption

Fluorescence

\begin{abstract}
The equilibrium binding of a new water-soluble tetra-cationic porphyrin, 5-(1-(4carboxybutyl)pyridinium-4-yl)10,15,20-tris(1-methylpyridinium-4-yl)porphyrin (5-CBPyP) with calf thymus DNA in comparison with meso-tetrakis(4- $N$-methylpyridinium)porphyrin (TMPyP) has been studied in $7.5 \mathrm{mM}$ phosphate buffer, $\mathrm{pH}=7.2$ and at various temperatures by UV-Vis absorption, fluorescence spectroscopies and viscosity measurement. The thermodynamic parameters were calculated by van't Hoff equation at various temperatures. The values of $-137.13 \pm 1.22 \mathrm{~kJ} / \mathrm{mol}$ and $-337.21 \pm 4.75 \mathrm{~J} / \mathrm{mol}$.K for $5-\mathrm{CBPyP}$ and $-159.12 \pm 1.22$ $\mathrm{kJ} / \mathrm{mol}$ and $-406.11 \pm 4.45 \mathrm{~J} / \mathrm{mol} . \mathrm{K}$ for TMPyP, were estimated for enthalpy and entropy changes of interaction, respectively. The data indicate that the process is exothermic and enthalpy driven suggesting that electrostatic forces play a considerable role in the interaction process. The results of spectroscopic techniques and viscosity measurement represent the intercalation mode of binding for both porphyrins and higher binding affinity of TMPyP respect to 5-CBPyP
\end{abstract}

\section{Introduction}

Cationic porphyrin macrocycles represent a large and expanding class of compounds which have application in biology, medicine, catalysis, and materials [1]. Interaction porphyrins and metalloporphyrins with DNA have a considerable interest due to their medical applications. Their special properties: high optical absorption, relatively high quantum yields of triplet state and fluorescence, or paramagnetism of some metal complexes, provide the use of porphyrin in medicine, as active compounds in radiological $[2,3]$, magnetic resonance imaging $[4,5]$ of cancer detection and as photosensitizers in photodynamic therapy (PDT) of cancer [6,7]. Porphyrin demonstrates the photodynamic activity against psoriasis atheromatous plaque, viral and bacterial infections including HIV as well [8].

Cationic porphyrins are considered as double functional compounds that strongly bind to DNA and photodynamically modify the target site of a DNA molecule by a mechanism similar to that of anti-cancer antibiotics such as bleomycin and daunomycin based on the DNA cleavage [9-11]. The interaction of cationic porphyrins with synthetic and natural DNA and other biological molecules has been widely studied using visible absorption spectroscopy and circular dichroism (CD), fluorescence, Raman, NMR, ESR, viscometry, foot printing, kinetic methods and X-ray crystallography [12-37].

There are a number of advantages of studying the DNA binding interactions of cationic metalloporphyrins [38,39]. First, that these molecules bind to nucleic acids in ways similar to "real" anti-tumor drugs, i.e., by intercalative or external binding modes, makes these porphyrins powerful probes of drug-DNA interactions, as well as DNA structure. Second, their high solubility and weak tendency to aggregate in water (except at very high porphyrin concentrations) make them suitable for investigation under a wide variety of solution conditions. Third, by varying the metal center and peripheral substituents, the porphyrin's binding mode to nucleic acid duplexes can be easily "tuned" to be the intercalative or external type.

The binding strength of porphyrin to DNA is one of the important parameters on its efficacy. The thermodynamic parameters of binding can also help us to obtain more insights into the molecular nature of interactions. Hence, determination of thermodynamic parameters governing DNA-porphyrin complex formation makes deeper insight into molecular basis of DNA-porphyrin interactions.

The extensive exploration of cationic porphyrins has been hitherto limited to cationic porphyrins with alkyl connected 4-position of pyridine and its various derivatives. Introducing some bioactive moieties onto the periphery of the porphyrin has been performed in DNA photocleavage and antitumor [40]. The binding mode of porphyrin-DNA is affected by location of the substituent groups on the periphery of the porphyrins $[41,42]$.

In the present study, the interaction of a new water-soluble tetracationic porphyrin, 5-(1-(4-carboxybutyl) pyridinium-4yl)10,15,20-tris(1-methylpyridinium-4-yl)porphyrin CBPyP), with calf thymus deoxy ribose nucleic acid (ct-DNA), has been studied in comparison with meso-tetrakis (4- $\mathrm{N}$ methylpyridinium) porphyrin (TMPyP), with positively charged pyridinium groups (Scheme 1). The study was done using various techniques such as UV-Vis absorption, fluorescence spectroscopy and viscosity measurement. Running the interaction experiments at various temperatures, 
let us to estimate all of the thermodynamic parameters of interactions and obtain useful information regard binding mechanism.
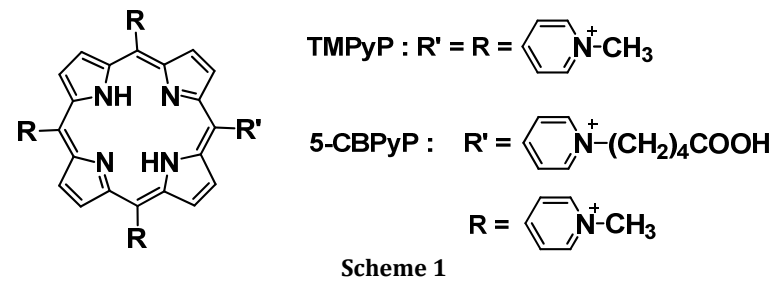

\section{Materials and methods}

Porphyrins were prepared and purified according to literature methods [43,44]. 5,10,15,20-tetrapyridyl porphyrin (TPyP) (Fluka), 5-bromopentanoate, methyl iodide (Acros chemicals) were used as received. TMPyP was obtained by methylation of TPyP [12]. For the preparation of 5-CBPyP, TPyP was alkylated with an excess of ethyl 5-bromopentanoate in $\mathrm{CHCl}_{3} / \mathrm{EtOH}$, leading to a mixture of different $N$-alkylation products, out of which 5-(1-(4-ethoxycarbonyl)butyl)pyridini um-4-yl)-10,15,20-tripyridylporphyrin bromide was separated by chromatography on a short silica gel column and obtained in a reasonable $33 \%$ yield. The present preparation afforded the ester in a large scale associated with an easy separation of expected isomer. The remaining three free pyridine substituents were then quantitively alkylated by methyl iodide to afford the teracationic porphyrin. The ester function was hydrolyzed with aqueous $\mathrm{HCl}$ to the corresponding acid 5CBPyP in $91 \%$ yield. The precipitated iodide salt of porphyrins were dissolved in $0.1 \mathrm{~N} \mathrm{HCl}$ and then applied to an ionexchange column (Dowex $1 \times 8 \mathrm{Cl}^{-}$form resin, mesh size 200$400 \mathrm{~nm}$, Merck) to replace the counter anion with the chloride ion.

All experiments were run in phosphate buffer (consisted of $2.5 \mathrm{mM} \mathrm{NaH}_{2} \mathrm{PO}_{4}+5 \mathrm{mM} \mathrm{Na}_{2} \mathrm{HPO}_{4}$ dissolved in Milli-Q quality water) at $\mathrm{pH}=7.2$. Calf thymus DNA was purchased from Sigma. To prepare ct-DNA stock solution; 2 mg of DNA was dissolved in $1 \mathrm{~mL}$ of phosphate buffer the day before the experiment and stored at $4{ }^{\circ} \mathrm{C}$. The concentration of DNA and porphyrins were determined from their optical absorption using molar absorption coefficients $\varepsilon^{260 \mathrm{~nm}}=1.320 \times 10^{4} \mathrm{M}^{-1} \cdot \mathrm{cm}^{-1}$ for ct-DNA (i.e. reported in molar base pairs) and $\mathcal{E}^{423 \mathrm{~nm}}=2.492 \times 10^{5} \mathrm{M}^{-1}$. $\mathrm{cm}^{-1}, \quad \varepsilon^{423 \mathrm{~nm}}=1.588 \times 10^{5} \mathrm{M}^{-1} . \mathrm{cm}^{-1}$, for TMPyP and 5-CBPyP, respectively, at their Soret bands $[45,46]$. The titration was made by addition of the ct-DNA stock solution into a $1 \mathrm{~mL}$ cuvette containing the porphyrin solution of appropriate concentration.

For the optical absorption experiments the porphyrin solutions were prepared in concentrations varying in the range from 3 to $50.0 \mu \mathrm{M}$. The absorption spectra were recorded on Cary 500 scan UV-Vis-NIR spectrophotometer. The spectrophotometric titration experiments were run at various temperatures.

Emission spectra of Ethidium bromide (EB) bound to DNA in the absence and presence of the TMPyP and 5-CBPyP were recorded on a spectrofluorimeter Shimadzu model RF-5000. In a typical experiment, titration of a mixed DNA and EB solution with porphyrin in phosphate buffer was performed by stepwise addition of porphyrin solution in the same buffer directly to the cuvette. The concentration of DNA and EB were $1.50 \times 10^{-5}$ and $5.00 \times 10^{-6} \mathrm{M}$, respectively. The solutions were excited at $515 \mathrm{~nm}$ and the emitted light intensity was measured in the range of $520-800 \mathrm{~nm}$. Both UV-Vis and fluorescence spectra were also corrected for dilution. The temperature was kept constant with $\pm 1{ }^{\circ} \mathrm{C}$ during titration experiments.
The viscosity of ct-DNA solutions was measured at $30 \pm 0.1^{\circ} \mathrm{C}$ using an Ubbelohde viscometer. Typically, $10.0 \mathrm{~mL}$ of phosphate buffer was transferred to the viscometer to obtain the reading of flow time. For determination of solution viscosity, $10.0 \mathrm{~mL}$ of buffered solution of $160 \mu \mathrm{M}$ ct-DNA was taken to the viscometer and a flow time reading was obtained. An appropriate amount of porphyrin was then added to the viscometer to give a certain $r$ ( $r=$ [porphyrin]/[DNA base pair]) value while keeping the ct-DNA concentration constant, and the flow time was read. The flow times of samples were measured after the achievement of thermal equilibrium (30 min). Each point measured was the average of at least five readings. The data obtained were presented as relative viscosity, $\eta / \eta_{\mathrm{o}}$ versus $r$, where $\eta$ is the reduced specific viscosity of DNA in the presence of porphyrin and $\eta_{\mathrm{o}}$ is the reduced specific viscosity of ct-DNA alone [32,33].

\section{Results and discussion}

\subsection{The analysis of the optical absorption spectra}

The optical absorption spectrum of both porphyrins shows four Q-bands and a Soret band feature. Beer's law experiments were carried out for porphyrins in homogeneous aqueous solutions at $\mathrm{pH}=7.2$ and the molar absorptivity of these bands were calculated. The fixed amount of cationic porphyrins $(3 \mu \mathrm{M}$ of TMPyP and $5.3 \mu \mathrm{M}$ of 5-CBPyP) in phosphate buffer was titrated with a stock solution of ct-DNA at the various temperatures. The spectral features of studied porohyrins at various DNA concentrations were shown in Figure 1 and 2. As shown in these figures, the intensity of the Soret band at 424 $\mathrm{nm}$ decreased at the earlier addition of DNA. The observed red shift of the Soret band during the titration suggests the binding of the porphyrin to ct-DNA. Cationic porphyrin TMPyP exhibited $62 \%$ hypochromism and $15 \mathrm{~nm}$ red shift of the Soret band, however in the case of 5-CBPyP changes with 37\% hypochromism and $11 \mathrm{~nm}$ red shift of the Soret band in UV-Vis spectra was observed.

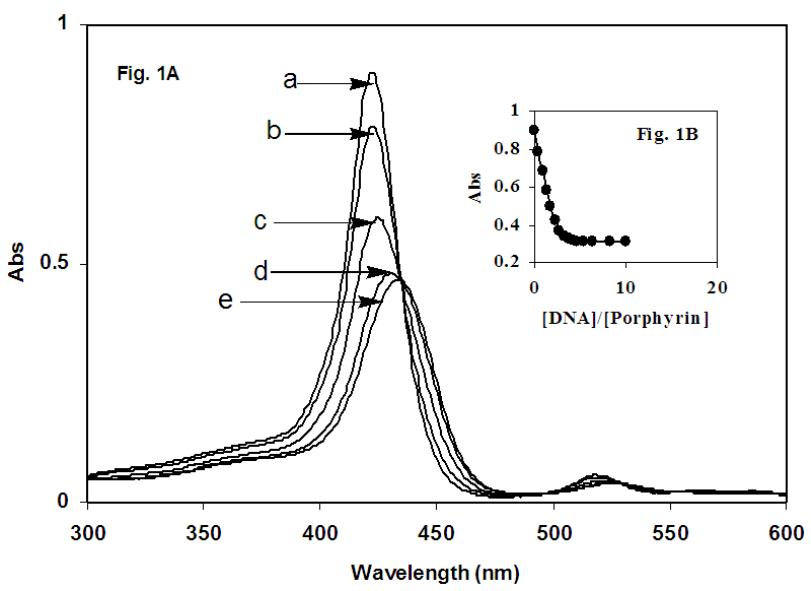

Figure 1. (A). Absorption spectra of TMPyP $(3 \mu \mathrm{M})$ in the absence (a) and presence of calf thymus-DNA; $1.3 \mu \mathrm{M}$ (b), $3.8 \mu \mathrm{M}$ (c), $6.2 \mu \mathrm{M}$ (d), $7.5 \mu \mathrm{M}$ (e) in $7.5 \mathrm{mM}$ Phosphate buffer, $\mathrm{pH} 7.2$ and at $25{ }^{\circ} \mathrm{C}$. (B) The variation of absorbance at the Soret band ( $424 \mathrm{~nm}$ ) versus mole ratio of DNA to TMPyP.

The intercalative binding porphyrins to a DNA helix has been characterized by: (i) large red shift $(\Delta \lambda \geq 15 \mathrm{~nm})$ and hypochromic $(\mathrm{H} \geq 35 \%)$ shifts of their Soret maxima, (ii) negative $(-)$ induced $C D$ activity in the Soret region, and (iii) high selectivity for GC-rich DNA sequences [12]. In contrast, outside binders displayed: (i) much smaller red shifts $(\Delta \lambda \leq 8$ $\mathrm{nm})$ and little hypochromicity $(\mathrm{H} \leq 10 \%)$, and sometimes hyperchromicity of their Soret maxima, (ii) positive (+) induced $\mathrm{CD}$ bands in the Soret region, and (iii) a distinct preference for 
AT-rich minor groove segments. With respect to the mentioned documents, our studied porphyrins bind to DNA through intercalation. The presence of isosbestic points in their UV-Vis titration spectra confirms the homogeneous binding mode (Figure 1 and 2).

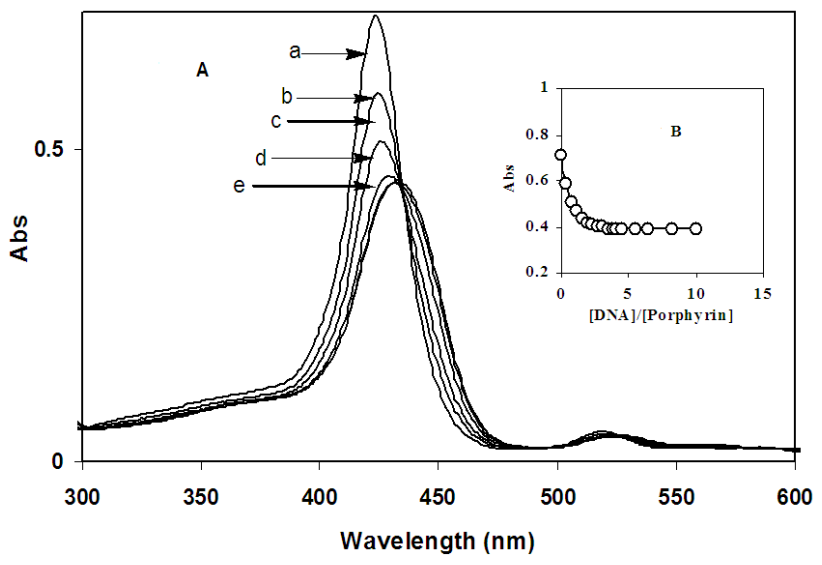

Figure 2. (A). Absorption spectra of 5-CBPyP $(5.3 \mu \mathrm{M})$ in the absence (a) and presence of calf thymus-DNA; $1.98 \mu \mathrm{M}$ (b), $13.9 \mu \mathrm{M}(\mathrm{c}), 15.9 \mu \mathrm{M}$ (d), $17.9 \mu \mathrm{M}$ (e), in $7.5 \mathrm{mM}$ phosphate buffer, $\mathrm{pH}=7.2$ and at $25^{\circ} \mathrm{C}$. (B) The variation of absorbance at the Soret band ( $423 \mathrm{~nm}$ ) versus mole ratio of DNA to 5-CBPyP.

Binding constants for the interaction of cationic porphyrins with DNA were determined by analysis of absorption spectrophotometric titrations data. The changes in absorbance of the Soret band upon addition of DNA were monitored at the maximum of the Soret band. The apparent binding constant, $\mathrm{K}_{\mathrm{app}}$ of cationic porphyrins to DNA was calculated using Eq. 1

$$
\frac{[D N A]_{\text {total }}}{\left(\left|\varepsilon_{\text {app }}-\varepsilon_{f}\right|\right)}=\frac{[D N A]_{\text {total }}}{\left(\left|\varepsilon_{b}-\varepsilon_{f}\right|\right)}+\frac{1}{K_{a p p}\left(\left|\varepsilon_{b}-\varepsilon_{f}\right|\right)}
$$

Where $\varepsilon_{a p p}, \varepsilon_{f}$ and $\varepsilon_{b}$ correspond to Aobsorved/[porphyrin], the extinction coefficient for the free porphyrin and the extinction coefficient for the porphyrin in the fully bound form, respectively. In the plot of $\frac{[D N A]_{\text {total }}}{\left(\left|\varepsilon_{a p p}-\varepsilon_{f}\right|\right.}$ versus $[D N A]_{\text {total }}, K_{a p p}$ is given by the ratio of the slope to the intercept [47-49]. The apparent binding constants of TMPyP and 5-CBPyP were estimated and used for calculation of Gibbs free energy change of reaction at various temperatures.

\subsection{Thermodynamics of DNA-porphyrin binding process}

The energetics of protein-ligand equilibrium can be conveniently characterized by three thermodynamic parameters; the standard Gibbs free energy, $\Delta G^{\circ}$, the standard molar enthalpy, $\Delta H^{\circ}$, and the standard molar entropy, $\Delta S^{\circ}$. $\Delta G^{\circ}$ can be calculated from the equilibrium constant, $K$, of the reaction using the familiar relationship, $\Delta G^{o}=-R T \ln K$ in which $R$ and $T$ are gas constant and the absolute temperature, respectively. If heat capacity change for the reaction, $\Delta C_{p}^{o}$, is essentially zero, the van't Hoff equation (Eq. 2) gives a linear plot of $\ln \mathrm{K}$ versus $1 / T$.

$$
\partial \ln K=-\left(\Delta H^{o} / R\right) \partial\left(\frac{1}{T}\right)
$$

The standard enthalpy and entropy change of binding can be estimated from the slope and Y-intercept of the plot of $\Delta G^{\mathrm{o}} / T$ versus $1 / T$, respectively. Such plots for binding of these porphyrin complexes to DNA in phosphate buffer are shown in Figure 3 and their calculated thermodynamic parameters at $25{ }^{\circ} \mathrm{C}$ are reported in Table 1 . The obtained linear van't Hoff plots have indicated that there is no change in heat capacity over the temperature range $20-40{ }^{\circ} \mathrm{C}$. Therefore, the values obtained for $\Delta G^{\circ}, \Delta H^{\circ}$ and $\Delta S^{\circ}$ serve as thermodynamic parameters of porphyrin-DNA interactions. It has been revealed that the standard free-energy changes for porphyrinDNA interaction are large and negative that representing relative high affinity of these porphyrins to DNA. It has also been indicated that the binding process is exothermic for both porphyrins. The calculated thermodynamic parameters represent the lower affinity and smaller exothermicity of 5CBPyP binding to DNA. In the other word, the lower affinity of 5 -CBPyP has enthalpic origin. The enthalpic nature of the reaction can be related to the significant role of electrostatic interactions in binding process. A convenience interpretation of such observation can be related to the introduction of a negative charge on the perphery of the 5-CBPyP (the $\left(\mathrm{CH}_{2}\right)_{4} \mathrm{COOH}$ moiety is fully deprotonated at $\left.\mathrm{pH}=7.2\right)$. The presence of such negative charge should hamper the interaction with the negatively charged phosphate groups of the nucleic acid. This can be also the origin of the unanticipated result of diffiusion into the double helix from opposite site of substitution. The binding of porphyrins are enthalpically driven, with unfavorable entropic contribution that may be a result of disrupted structured water because of the interaction of the hydrophobic forces ( $\pi$ system of macrocycle) with water at each porphyrin structure.

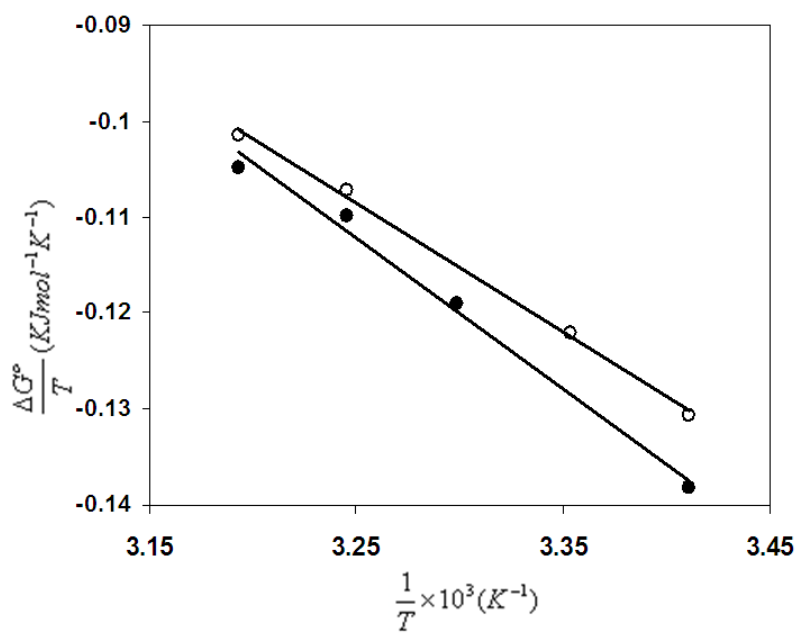

Figure 3. The van't Hoff plots of DNA-Binding of TMPyP $(\bullet)$ and 5-CBPyP (O).

Table 1. Calculated thermodynamic parameters for binding of 5-CBPyP and TMPyP to ct-DNA in $7.5 \mathrm{mM}$ phosphate buffer $\mathrm{pH}=7.2$, at $25^{\circ} \mathrm{C}$.

\begin{tabular}{lcccc}
\multicolumn{5}{l}{ TMPyP to ct-DNA in 7.5 mM phosphate buffer $\mathrm{pH}=7.2$, at $25^{\circ} \mathrm{C}}$. \\
Compound & $\begin{array}{c}\mathbf{L o g} \mathbf{K} \\
(\mathbf{1} / \mathbf{M})\end{array}$ & $\begin{array}{c}\Delta \mathbf{G}^{\mathbf{o}} \\
(\mathbf{k j} / \mathbf{m o l})\end{array}$ & $\begin{array}{c}\Delta \boldsymbol{H}^{\mathbf{o}} \\
(\mathbf{k j} / \mathbf{m o l})\end{array}$ & $\begin{array}{c}\Delta \boldsymbol{S}^{\mathbf{o}} \\
(\mathbf{j} / \mathbf{m o l})\end{array}$ \\
\hline 5-CBPyP & $6.53 \pm 0.01$ & $-37.25 \pm 0.11$ & $-137.73 \pm 1.22$ & $-337.21 \pm 4.75$ \\
TMPyP & $6.79 \pm 0.01$ & $-38.73 \pm 0.16$ & $-159.75 \pm 1.22$ & $-406.11 \pm 4.45$ \\
\hline
\end{tabular}

\subsection{Viscosity}

Optical or photophysical probes generally provide necessary, but not sufficient, clues to support an intercalativebinding model. Hydrodynamic measurements that are sensitive to length increases (i.e. viscosity, sedimentation, rotational diffusion as measured by transient electric diffusion) are the least ambiguous and most critical tests of the intercalation model in solution. The DNA helix lengthens as the base pairs are separated to accommodate the bound ligand for the intercalation of the molecule, leading to increase in DNA viscosity. Hydrodynamic methods are thus suitable to detect 
such changes and, in the absence of crystallographic structural data, provide essential evidence to support the intercalation model. In contrast, partial and/or nonclassical intercalation of ligands could bend (or kink) the DNA helix, reduce its effective length and in turn, its viscosity. The effect of TMPyP and 5 -CBPyP on the viscosity of DNA is shown in Figure 4. The relative viscosity of DNA increases with increase in the concentration of the two porphyrins, a behavior which is similar to that of the classical intercalator (i.e. ethidium bromide) [50-52]. The viscosity results unambiguously show that TMPyP and 5-CBPyP porphyrin bind with DNA by an intercalative mode, this results are in agreement with optical absorption experiments.

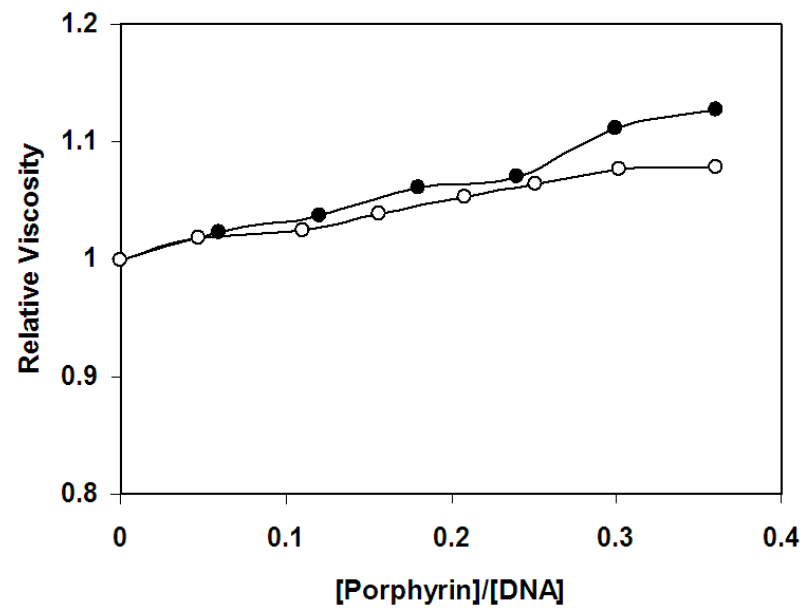

Figure 4. Effect of increasing amounts of TMPyP $(\bullet)$ and 5-СBPyP $(O)$ on the relative viscosities of ct-DNA at $30 \pm 0.1{ }^{\circ} \mathrm{C}$ and [DNA] $=160 \mu \mathrm{M}$ ( $\mathrm{r}=[$ Porphyrin/[DNA]).

\subsection{Fluorescence spectroscopic studies}

Ethidium bromide (EB) emits intense fluorescence light in the presence of DNA, due to its strong intercalation between the adjacent DNA base pairs. It was previously reported that the enhanced fluorescence can be quenched by the addition of a second molecule $[53,54]$. The quenching extent of fluorescence of EB bound to DNA is used to determine the extent of binding between the second molecule and DNA. The emission spectra of EB bound to DNA in the absence and the presence of TMPyP and 5-CBPyP are given in Figure 5A and 6A, respectively. In this case, the reduction in emission intensity could be due to displacement of EB from the interaction sites by these porphyrins, and representing that binding constants of these porphyrins to ct-DNA are comparable with binding constant of EB to DNA which is in the order of $10^{6} \mathrm{M}^{-1}$ [53].

According to the classical Stern-Volmer equation [54]:

$$
\frac{I_{\circ}}{I}=1+K_{s v} r
$$

Where $I_{0}$ and $I$ are the fluorescence intensities in the absence and the presence of porphyrin, respectively, $K_{\mathrm{sv}}$ a linear SternVolmer quenching constant, $r$ the ratio of total concentration of porphyrin that of DNA. The fluorescence quenching curves of EB bound to DNA by the porphyrins are shown in Figure 5B and 6B. The quenching plots illustrate that the quenching of $\mathrm{EB}$ bound to DNA by the porphyrins are in good agreement with the linear Stern-Volmer equation, which also proves that the porphyrins bind to DNA. In the plot of $I_{0} / I$ versus [porphyrin]/[DNA], $K$ is given by the ratio of the slope to intercept. The values of 45.62 and 14.14 were estimated for $K_{s v}$ of TMPyP and 5-CBPyP, respectively. Such values of quenching constant suggest that the interaction of these porphyrins with DNA is of strange intercalation $[53,55]$.

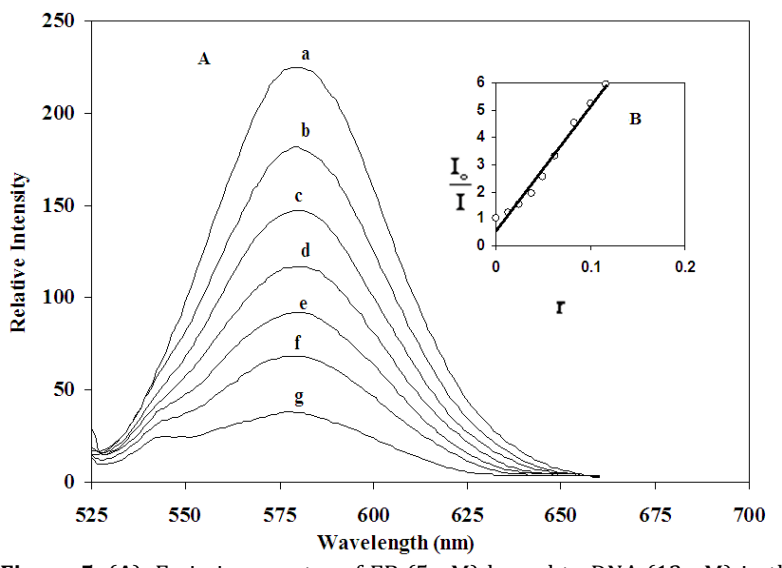

Figure 5. (A). Emission spectra of EB $(5 \mu \mathrm{M})$ bound to DNA $(12 \mu \mathrm{M})$ in the absence (a) and presence of TMPyP; $0.15 \mu \mathrm{M}$ (b), $0.3 \mu \mathrm{M}$ (c), $0.45 \mu \mathrm{M}$ (d), $0.60 \mu \mathrm{M}(\mathrm{e}), 0.75 \mu \mathrm{M}$ (f), $0.90 \mu \mathrm{M}(\mathrm{g})$, in $7.5 \mathrm{mM}$ phosphate buffer, $\mathrm{pH}=7.2, \lambda_{\mathrm{ex}}$ $=510 \mathrm{~nm}$. (B) The corresponding Stern-Volmer plot for quenching process of EB by TMPyP.

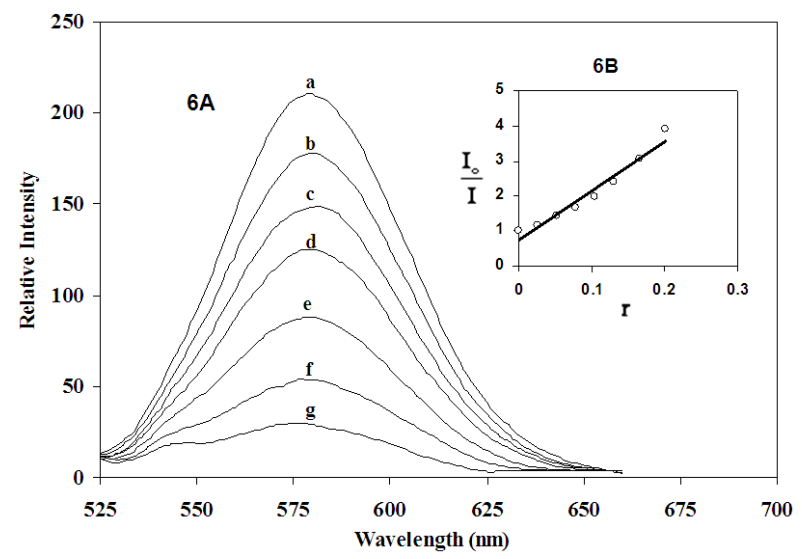

Figure 6. (A). Emission spectra of EB $(5 \mu \mathrm{M})$ bound to DNA $(12 \mu \mathrm{M})$ in the absence (a) and presence of 5-CBPyP; $0.31 \mu \mathrm{M}(\mathrm{b}), 0.62 \mu \mathrm{M}(\mathrm{c}), 0.94 \mu \mathrm{M}$ (d),1.25 $\mu \mathrm{M}$ (e), $1.56 \mu \mathrm{M}$ (f), $1.88 \mu \mathrm{M}$, in $7.5 \mathrm{mM}$ phosphate buffer, $\mathrm{pH}=7.2$, $\lambda_{\text {ex }}$ $=510 \mathrm{~nm}$. (B) The corresponding Stern-Volmer plot for quenching process of EB by 5-CBPyP.

\section{Acknowledgement}

The financial supports of Research Council and Center for Graduate studies of Isfahan University and Guilan University are gratefully acknowledged.

\section{References}

[1]. Anderson, M. E.; Barrett, A. G. M.; Hoffman, B. M. J. Inorg. Biochem. 2000, 80, 257-260.

[2]. Hambright, P.; Fawwaz, R.; Valk, P.; McRac, J.; Bearden, A. J. Bioinorg Chem. 1975, 5, 87-92.

[3]. Zanelli, G. D.; Kaclin, A. C. Br. J. Radiol. 1981, 53, 403-407.

[4]. Chen, C.; Cohen, J. S.; Myers, C. E.; Sohn, M. FEBS Lett. 1984, 168, 7074.

[5]. Patronas, N. J.; Cohen, M.; Knop, R. H.; Dwyer, A. J.; Colcher, D.; Lundy, J.; Mornex, F.; Hambright, P.; Sohn, M.; Myers, C. E. Cancer Treatment Rep. 1986, 70, 391-395.

[6]. Del, A. M.; Batlle, C. J. Photochem. Photobiol. 1993, 20, 5-22.

[7]. Bonnett, R. Chem. Soc. Rev. 1995, 24, 19-33.

[8]. Ben-Hur, I.; Horowitz, B.; Photochem. Photobiol. 1995, 62, 383-388.

[9]. Pratviel, G.; Bernadou, J. Meunier, B. Metal Ions in Biological Systems, Marcel Dekker, New York, 1996.

[10]. Burger, R. M. Chem. Rev. 1998, 98, 1153-1169.

[11]. Niedle, S.; Sanderson, M. R. Molecular Aspects of Anti-cancer Drug Action, Verlag Chemie GmBH, Weinheim, 1983.

[12]. Pasternack, R. F.; Gibbs, E. J.; Villafranca, J. J. Biochemistry 1983, 22, 2406-2414.

[13]. Makundan, N. E.; Petho, G.; Dixon, D. W.; Marzilli, L. G. Inorg. Chem. 1995, 34, 3677-3687.

[14]. Pasternack, R. F. Chirality 2003, 15, 329-332. 
[15]. Yin, Y. B.; Wang, Y. N.; Ma, J. B. Spectrochimica Acta Part A 2006, 64, 1032-1038.

[16]. Luca,G. D.; Romeo, A.; Scolaro, L. M. J. Phys. Chem. B 2005, 109, 71497158.

[17]. Bordbar, A. K.; Tangestaninegad, S.; Eslami, A. J. Biochem. Mol. Biol. \& Biophys. 2001, 5, 143-152.

[18]. Bordbar, A. K.; Eslami A.; Tangestaninegad, S. J. Porphyr. Phthalocya. 2002, 6, 225-232.

[19]. Bordbar,A . K.; Ghaderi, A. R.; Safaei, E.; Tangestaninejad, S.; Eslami, E.; Saboury, A. A; Moosavi-Movahedi, A. A. Bull. Korean Chem. Soc. 2003, 24, 547-551.

[20]. Bordbar, A. K.; Eslami, A.; Tangestaninejad, S. Polish J. Chem. 2003, 77, 283-293.

[21]. Asadi, M.; Bordbar, A. K.; Safaei, E., Ghasemi, J. J. Mol. Struc. 2004, 705, 41-47.

[22]. Bordbar, A. K.; Davari, M.; Safaei, E.; Mirkhani, V. J. Porphyr. Phthalocya. 2007, 11, 139-147.

[23]. Bordbar, A. K.; Keshavarz, M. Biochem.: An Indian Journal 2007, 1, 1, 17.

[24]. Bordbar, A. K.; Keshavarz, M.; Zare K.; Aghaei, H. Phys. Chem. Liq. 2006, 44, 4, 457-464.

[25]. Bordbar, A. K.; Mohammadi, K.; Keshavarz, M.; Dezhampanah, H. Acta Chim. Slov. 2007, 54, 336-340.

[26]. Nafisi, S.; Saboury, A. A.; Keramat, N.; Neault, J. F.; Tajmir-Riahi, H. A. J. Mol. Struc. 2007, 827, 35-43.

[27]. Novy, J.; Urbanova, M; Volka, K. J. Mol. Struc. 2005, 748, 17-25

[28]. Sari, M. A.; Battioni, J. P.; Dupre, D.; Mansuy, D.; LePecq, J. B. Biochemistry, 1990, 29, 4205-4215.

[29]. Butje, K.; Schneider, J. H.; Kim, J. P.; Wang, Y.; Ikuta, S.; Nakamoto, K. J. Inorg. Biochem. 1989, 37, 119-134.

[30]. Strickland, J. A.; Marzilli, L. G.; Wilson, W. D.; Zon, G. Inorg. Chem. 1989, 28 4191-4198.

[31]. Dougherty, G.; Pasternack, R. F.; Biophys. Chem. 1992, 44, 9-11.

[32]. Banville, D. L.; Marzilli, L. G.; Strickland, J. A.; Wilson, W. D. Biopolymers 1986, 25, 1837-1858.

[33]. Gray, T. A.; Yue, K. T.; Marzilli, L. G. J. Inorg. Biochem. 1991, 41, 205219.

[34]. Ward, B.; Skorobogaty, A.; Dabrowiak, J. C. Biochemistry. 1986, 25, 7827-7833.

[35]. Ford, K.; Fox, K. R.; Neidle, S.; Waring, M. J. Nucl. Acids Res. 1987, 15, 2221-2234.

[36]. Pasternack, R. F.; Gibbs, E. J.; Vilafranca, J. J. Biochemistry 1983, 22, 5409-5417.

[37]. Lipscomb, L. A.; Zhou, F. X. Presnell, S. R.; Woo, R. J.; Peek, M. E.; Plaskon, R. R.; Williams, L. D. Biochemistry 1996, 35, 2818-2823.

[38]. Kang, J.; Wu, H.; Lu, X.; Wang, Y.; Zhou, L. Spectrochemica Acta Part A 2005, 61, 2041-2047.

[39]. Neault, H. F.; Tajmir-Riahi, H. A. Biophys. J. 1999, 76, 2177-2182.

[40]. Han, H.; Langley, D. R.; Rangan, A.; Hurley, L. H. J. Am. Chem. Soc. 2001, $123,902-8913$

[41]. Ding, L.; Casas, C.; Etemad-Moghadam, G.; Meunier, B. New J. Chem. 1990, 14, 421- 431 .

[42]. Marzilli, L. G. New J. Chem. 1990, 14, 409-420.

[43]. Casas, C.; Saint-James, B.; Lacey, C. J.; Munier, B. J. Org. Chem. 1993, 58, 2913-2917.

[44]. Jakobs, A.; Bernadou, J.; Meunier. B. J. Org. Chem. 1997, 62, 3505-3510.

[45]. Pasternack, R. F; Bustamante, C.; Collings, P. J.; Giannetto, A.; Gibbs, E. J. J. Am. Chem. Soc. 1993, 115, 5393-5399.

[46]. Pasternack, R. F.; Collings, J. P. Science 1995, 269, 935-939.

[47]. Pyle, A. M.; Rehman, J. P.; Meshoyrer, R.; Kumar, C. V.; Turro, N. J.; Barton, J. K. J. Am. Chem. Soc. 1989, 111, 3051-3058.

[48]. Onuki, J.; Ribas, A. V.; Medeiros, M. H. G. ; Araki, K.; Toma, H. E.; Catalani, L. H.; Mascio, P. D. Photochem. Photobiol. 1996, 63, 272-277.

[49]. Mettath, S.; Munson, B. R.; Pandey, R. K. Bioconj. Chem. 1999, 10, 94102.

[50]. Cory, M.; Mckee, D. D.; Kagan, J.; Henry, D. W.; Miller, J. J. Am. Chem. Soc. 1985, 107, 2528-2536.

[51]. Waring, M. J. J. Mol. Biol. 1965, 13, 269-282.

[52]. Hiort, C.; Lincoln, P.; Norden, B. J. Am. Chem. Soc. 1993, 115, 34483454 .

[53]. Baguley, B. C.; LeBret, M. Biochemistry 1984, 23, 937-943.

[54]. Lakowicz, J. R.; Webber, G.; Biochemistry 1973, 12, 4161-4170.

[55]. Liu, J.; Zhang, T. X.; Lu, T. B.; Qu, L. H.; Zhou. H.; Zhang, Q. L.; Ji, L. N. J. Inorg. Biochem. 2002, 91, 269-276. 